\title{
Pluralism, Group Rights, and Corporate Religion
}

\section{Reply to Critics}

\author{
Jean L. Cohen
}

My article focuses on an expansive conception of religious freedom propagated by a vocal group of American legal scholars, often working with well-funded conservative foundations like the Beckett Fund for Religious Liberty and influencing accommodation decisions throughout the US. ${ }^{1}$ Although not stated doctrine, religious status-group 'jurisdictional pluralism' is implicit in recent Supreme Court rulings and in the state Religious Freedom Restoration Acts (RFRAs) passed before and after Hobby Lobby. ${ }^{2}$ Recent critical work calls the shift in religion clause scholarship 'the new religious institutionalism'. ${ }^{3}$ But I see the logic of the jurisdictional approach also in the complicity-based, integralist conscience claims at issue in Hobby Lobby and in the proliferating demands for exemptions from anti-discrimination laws for religious individuals running for-profit businesses who do not want to cater to same sex couples. ${ }^{4}$ So I do not adopt the 'religious institutionalism' or 'church autonomy' labels because the demands reach beyond churches and religious institutions and pertain to individuals as well as to corporate business groups. My paper unearths the deeper logic, political projects and threats to liberal democratic constitutionalism underlying the new accommodationism.

Liberal constitutional democracies must prioritize democratic sovereignty in two ways: first, it is the prerogative and requirement of the civil polity to establish a just order whose ultimate source of law is the demos and whose legitimacy is based on immanent, democratic rather than meta-social guarantees; second, the civil polity and, ultimately, the sovereign citizenry has the competence to determine the competences of groups within the polity and to draw the line between public and private (which does not exclude regulation of the latter so that basic constitutional principles are not violated), guided by the core liberal premise of equal personal freedom and ethical independence for all. This precludes coercive enforcement of a comprehensive form of personal ethical life by the state, by the religious or by any other group. The supremacy and comprehensive scope of dem-

1 The Beckett Fund lists Hosanna-Tabor and Hobby Lobby among its top ten Supreme Court victories.

2 Twenty-one states have passed RFRAs.

3 Richard Schragger and Micah Schwartzman, 'Against Religious Institutionalism', Virginia Law Review 99(5) (2013): 917-85.

4 Indiana and Arkansas passed RFRAs, allowing businesses free exercise exemptions from anti-discrimination laws regarding same-sex couples. Under boycott pressure, Indiana's RFRA was amended to drop that stipulation. 
ocratic, accountable public power, and law are being challenged in subtle ways by the new accommodationism.

My aim was not to develop a liberal theory of permissible accommodations, but to reveal and criticize the assumptions underlying claims to a unique right to exemption for the religious from civil laws required by justice. Some exemptions to valid law are permissible on liberal-democratic secular grounds, so I do not adopt a Brian Barryish stance. ${ }^{5}$ It may be that to avoid discrimination, insensitivity, and unfairness, exemptions that do not undermine the general purpose of good and needed civil law may be required by justice. It may also be that the religious suffer distinct harms or have distinct claims. But 'distinct' is not 'unique', and none of the exemptions need or should entail deference to some other authority or jurisdiction or denials of competence by Courts to assess the relevant claims.

I focused on those 'accommodations' that undermine legitimate public purposes, violate the rights of others or entail direct, assignable third-party harms, i.e., exemptions to laws protecting individuals against odious discrimination or ensuring access to basic public services. ${ }^{6}$ The shift in deployment of accommodation demands from protecting religious minorities to permitting religious groups to undermine the rights of others - turning the rhetoric of free exercise of religion into a sword to liberate corporations and powerful religious organizations from government regulation - is an alarming trend. The deepest challenge is to the scope of civil government and its prerogative to regulate the worldly activities of the religious. I argued that the deference of the Court to the religious in HosannaTabor and Hobby Lobby ultimately entails an unjustifiable nod to a sovereignty claim other than that of the demos that both church autonomy (Hosanna-Tabor) and complicity conscience exemptions (Hobby Lobby) have come to rely on.

Recall that neither religious believers nor Christians are a minority in the US, nor are they oppressed or generally discriminated against. The new religious freedom and complicity-conscience claims are not classically separationist or about equality. Minority oriented multiculturalism is the wrong frame for grasping what really is at stake. The theorists influencing the legal opinions I criticize (among others) couch their religious group pluralism in the rhetoric of accommodation, radically shifting what had been a limited and benign practice aimed at inclusion and fair opportunity of religious freedom for religious minorities (pre-Smith ${ }^{7}$ ) to what may be turning, post-RFRA, into an unfair opportunity for the religious to discriminate against and harm others, undermine public purposes, enjoy immun-

5 Brian Barry, Culture and Equality: An Egalitarian Critique of Multiculturalism (Cambridge: Polity, 2001).

6 Laura S. Underkuffler, 'Odious Discrimination and the Religious Exemption Question', Cardozo Law Review 32(5) (2011): 2069-91.

7 Employment Division, Department of Human Resources of Oregon v. Smith, 494 US 872 (1990). In this case, the Court rejected the free exercise claim of two native Americans who lost their jobs for using peyote, an illegal substance, in a religious ceremony. 
ity from civil regulation and the power to rule over those in their control, while benefiting inordinately from state largess and deference.

I thus spent some time critically analyzing the resurrection by religious accommodationists of older pluralist literature precisely to make a jurisdictional claim. My point is that there is no good reason or need to reach back to any of this literature in order to argue for religious freedom, freedom of conscience or for fairness in treatment of religious groups in the US or elsewhere. Ordinary liberal freedoms of association, expression, privacy, and equality can handle all this perfectly well. Nor is there any reason to reiterate the British pluralist critique of what was even then tantamount to a caricature of state sovereignty and modern civil society. The pluralist alternative - that sovereignty should be divided among a plurality of associations, that the state is just one such association, and that social plurality should be re-constructed along quasi-corporatist lines - is unnecessary for associational freedom and was quickly abandoned at least by Laski once he realized the undesirable, even fascist implications of the corporatist pluralist position, not to mention its naïve anarchist impulses.

Adding a better understanding of the citizenship role would not rectify the problems inherent in segmental juridical pluralism. For it excludes the all important distinctions between public and private, civil and political society, voluntary civil associations that are necessarily partial in membership and the state as an allinclusive but also coercive organization, in whose respective societal community membership (citizenship) is not voluntary. The comprehensive jurisdiction of the state, its monopoly of the legitimate means of violence and of coercive law within a territory, makes it distinct from all civil associations and any theory contesting this has to come up with a feasible alternative. Perhaps some federal model would serve, but the need for public coercive law to constrain private and public power and violence, to accomplish public purposes, to resolve disputes among various public jurisdictions and protect individual rights will remain. ${ }^{8}$ Indeed, what differentiates the polity from lesser civil associations is its presumptive orientation to general public purposes and welfare, the impartial administration of justice and voice for all those subject to the law. This and its supremacy over all other groups is why impartiality, accountability, democratic inclusion and legitimacy, the rule of law, liberal limits, and social justice pertain to the state but not to civil society associations. I reject the parallelism or equivalence contemporary pluralist accommodationists hope to give to religious associations and their law vis-à-vis the political 'association' and its law. I reject the rejection of the primacy and comprehensive scope of democratic civil law (jurisdictional sovereignty) and hope to avoid the toxic jurisdictional mixing and constantly contested division of competences between religious and political elites that goes with jurisdictional pluralism. Religious ethics tend towards comprehensiveness and integralism, paradig- 
matically challenging the requirements of citizenship, civil law, constitutional principles, and public purposes of the liberal democratic civil state. The ultimate sovereignty question of who has the competence to decide conflicts over competences (what the Germans call Kompetenz-Kompetenz) is once again being raised by pluralists, this time deploying accommodationist rhetoric.

1. Avigail Eisenberg disagrees. She distinguishes between two approaches to religious freedom: religious group pluralism and religious group accommodationism. The former is jurisdictional seeking to limit state authority regarding the religious: a separation strategy in her view. The latter is a multicultural project seeking inclusion of religious minorities in the civil public sphere on fair terms. I allegedly confound them when I criticize religious pluralist accommodationism. Worse, I repeat tired and misguided critiques of multiculturalism that conflate political and legal strategies aimed at ensuring fair and equitable treatment of minorities with illiberal and in-egalitarian practices that have the opposite aim, thereby letting the illiberal majoritarians off the hook.

These charges miss their mark. Eisenberg grants that I myself draw the very distinction she makes. Moreover, it is the religious accommodationists who resurrect pluralist discourse to frame and justify their exemption demands. Thus, one must reflect on the deep structure of their rhetoric and analyze the astounding deference accorded uniquely to the religious by Courts and legislatures influenced by them. Precisely because we do have well-developed privacy, associational and expressive constitutional freedoms, robust first amendment protection of religious exercise, and a thriving plural civil society, the US already does a good job in protecting the autonomy of religious and other associations. So why resurrect jurisdictional pluralism? Why insist that the Constitution guarantees a unique privilege of exemption from the regulation of self-regulation only of religious associations and why defer to expansive worldly claims of religious integralists - individuals or groups - when these undermine basic rights and public purposes?

Eisenberg purports to reread the cases in the multiculturalism frame, despite her apparent sympathy for pluralist theories of the state. For her, Hosanna-Tabor and Hobby Lobby are inclusive accommodation cases in which the competing interests were, perhaps, not properly balanced. Oddly, she concedes the plausibility of the jurisdictional pluralist reading of Hobby Lobby, a much harder argument to make, although I try to do it. So let us return to the cases.

Ostensibly, both Hosanna-Tabor and Hobby Lobby are about justice. Certainly, the interests in both cases were not properly balanced: in Hosanna Tabor the interest of a schoolteacher fired for disability and for contacting the Equal Employment Opportunity Commission (EEOC) were given short shrift as were the third-party 
harms of women employees denied contraception in Hobby Lobby. ${ }^{9}$ But framing Hosanna-Tabor as a multicultural inclusion case is possible only if one ignores the very disturbing aspects of the Court's opinion in which it invokes the premodern version of freedom of the Church and the correlative legal pluralist conception of church autonomy, while denying its own competence to judge who is a minister for purposes relevant to constitutional issues and matters of labour law. While the Court insisted in a footnote that it is deciding the case on the merits, not on jurisdictional grounds, the mere fact that it felt compelled to do so is revealing. Indeed, it ends up giving jurisdictional prerogatives to 'the Church' by deferring to its claim to discretion over employees who are ministers, denying its own competence to judge such matters and hence to do the relevant line drawing with respect to the relevance of ministerial status in particular instances. The Court yielded untrammelled discretion over all employees in church owned (non-profit) institutions. Constitutionalizing the ministerial exemption in this way gave religious associations unique powers and immunities and foreclosed future lawsuits by employees of church owned universities, schools, hospitals, etc.

Eisenberg knows that civil courts can hardly refrain from determining what is religious and whether someone is a minister. If one invokes the free exercise clause for an accommodation, a Court has to determine whether it is dealing with a religious group and a religious claim. Unsurprisingly, in Hosanna-Tabor both the Court and Eisenberg focus on the sincerity issue. It was easy to acknowledge Perich was a minister as she was ordained. But it would have been just as easy to focus on the fact that she taught primarily secular subjects in a school, and it was from this job that she was fired for having exercised her right as an employee to complain to the EEOC. Whether the firing was about religion or about money, it became a jurisdictional issue.

Nor is sincerity the key issue regarding the constitutionalized ministerial exception. It does matter, as evidenced by a recent memo of the Southern Baptist Convention $(S B C)$ to member organizations urging them to designate all their employees as ministers so as to avoid labour law regulations and civil oversight of their employment practices! ${ }^{10}$ But the real question is why even the religiously sincere should get a free pass when it comes to labour law. Why should a religious non-profit be accorded the power to exercise their own discretion regarding employment regulation beyond the most narrowly construed exercise of priestly

9 See Frederick Mark Gedicks and Andrew Koppelman, 'Invisible Women: Why an Exemption for Hobby Lobby Would Violate the Establishment Clause', Vanderbilt Law Review En Banc 67 (2014): 51-66; Kara Loewenthal, 'When Free Exercise is a Burden: Protecting "Third Parties" in Religious Accommodation Law', Drake Law Review 62 (2014): 433-502; and Douglas NeJaime and Reva Siegal, 'Conscience Wars: Complicity-Based Conscience Claims in Religion and Politics', Yale Law Journal 124 (2015): 2516-91.

10 Protecting Your Ministry From Sexual Orientation Gender Identity [sic] Lawsuit. This is a manual coauthored by a commission of the SBC and an anti-gay legal organization - the Alliance Defending Freedom. The Protecting Your Ministry manual instructs religious employers to layer religious duties on top of each of their employees' actual job descriptions (from janitors to teachers) in an effort to convince courts that every single one of these employees qualifies as a minister. 
functions and choice of such ministers in a church? Why should a school be exempt from complying with very important public purposes and allowed to harm third parties, indeed, to discriminate on any ground whatsoever, just because it is a non-profit owned by the religious and just because its employees are labelled ministers? Given the large role of private religious schools and universities and the lack of good alternative schooling for the poor in the US, the denial of its own competence to determine competences and to regulate because it 'cannot judge' religious doctrine on the part of a civil court is alarming.

The real issue in Hosanna-Tabor was not who is a minister, it was whether teachers of secular subjects in a school owned by a church and, by implication, all employees in religious institutions and their non-profits are protected by civil law against discrimination on the basis of age, race, disability or even religion in nonreligiously relevant jobs. The rhetoric in the Court's decision reveals the deep logic behind the hands off attitude uniquely for religious associations. I argue that, ultimately, a political theological jurisdictional conception of church autonomy is doing the work. This is clear given the denial of equivalent autonomy claims for other civil groups and the refusal to let associational freedom control here. I am aware that the jurisdicational pluralists want to impose the jurisdictional interpretation on this decision to further their agenda. I thus sympathize with legal scholars who want to avoid such an interpretation so as to scale back the astonishing expansion of the ministerial exception by the Roberts Court. ${ }^{11}$ But the genie is out of the bottle, and we have to confront head on the jurisdictional and sovereignty issues such decisions raise. The danger to civil rights and civil oversight of religious organizations is real. Indeed, recently, a Kentucky appeals court denied any remedy for the dismissal of two tenured professors at the Lexington Theological Seminary even though it was known when they were hired that they did not share the Disciples of Christ faith. If this is what the ministerial exception means, then tenure contracts are not worth the paper they are written on and professors in large universities owned by religious institutions, like Notre Dame, better beware.

Eisenberg argues that from the jurisdictional pluralist perspective the Court's recognition of Hobby Lobby's religious freedom is a way to facilitate the purpose for which it was incorporated: to run a business based on religious values. But she argues that the state should not extend religious rights to groups that incorporate for-profit. The non- and for-profit distinction is crucial for her and apparently renders the jurisdictional reading plausible. Why? Why should not religious purposes extend into the market place? Pace Eisenberg, I do not think the non- and for-profit distinction for corporate religious freedom is the key here. I do not think that Notre Dame University, a non-profit corporation owned by the Catholic Church, should be exempt from the contraception mandate for employees any more than a for-profit business should be. My point regarding Hobby Lobby is that a business corporation is not a religious membership institution but neither 
is a non-profit university - both have employees (or students) of different or no faiths! It is worth noting that in the 1983 Bob Jones Case a university owned by a religious entity lost its non-profit tax-exempt status because it discriminated on the basis of race. ${ }^{12}$ But this was under a very different Court. Hobby Lobby should not have been given standing because employees did not join a religious membership organization when they took their jobs and Hobby Lobby is not affiliated with any church or religious organization. Corporations do not have independent moral standing on their own, Hobby Lobby is not an expressive business like the NY Times, so any ascription of religious purposes or ethos to the business corporation and any attempt to justify free exercise exemptions must deal with the issue of membership: whose voices and whose ethical integrity counts?

Now, one could argue that Hobby Lobby is not about corporate rights or jurisdictional pluralism at all because the issue for the owners of these 'closely held' corporations was that they, as individuals, wanted to run their businesses in ways congruent with their beliefs and did not want to be complicit with sin by contributing to a health insurance scheme that pays for contraception they object to on religious grounds. So the political theological sovereignty argument about the corporate religious is much harder to make here than in Hosanna-Tabor! There is the initial problem of veil piercing and that gets us part of the way. But the Court dismissed this as well as the relevance of the for-/non- profit distinction. It took the conscience complicity claims of the individual owners seriously, declaring that religious freedom means that they have a right to imbue their businesses with a religious ethos and run them congruent with their religious beliefs.

Let us assume sincerity. Complicity-based conscience claims refer to the conduct of third parties outside the faith community with which the claimant has a connection - here through money - and which, if the claims are granted, may risk third-party harms. ${ }^{13}$ Exemptions in complicity conscience cases are not tantamount to a negative liberty or to honouring a request for separation so as to dissociate from sinners or 'the world'. Instead, they entail a 'right' to control the behaviour of people from whom the employer operating in the market economy cannot dissociate as they are connected, however, indirectly, through money. In effect, the Hobby Lobby exemption permits the owners to dictate to the government how (or even if) funding for contraceptive coverage will be delivered and how (or if) it will be collected for employees under the control of the religious owners! ${ }^{14}$ The same logic applies to how their employees use their wages - a daunting prospect. I agree with Nomi Stolzenberg that it is the religious owners who are unaccommodating, having abandoned the traditional willingness of

12 Bob Jones University v. United States, 461 US 574 (1983). This case concerned the university's policy of banning interracial dating and marriage among its students on religious grounds.

13 NeJaime and Siegel, 'Conscience Wars: Complicity-Based Conscience Claims in Religion and Politics'.

14 Paraphrasing Nomi Stolzenberg, 'It's About the Money: The Fundamental Contradiction of Hobby Lobby', <http://weblaw.usc.edu/centers/clhc/events/feature/documents/Stolzenbergs paper.pdf>. 
Christians either to accommodate the secular world - here the monetized market economy - and to comply with its civil law rules, or to leave the world of sin, and not dirty their hands by entering into certain kinds of business or governmental activities. ${ }^{15}$

In Hobby Lobby we are dealing with expansive and aggressive worldly integralists who demand that the world they come into contact with, even if indirectly, conform to their purist religious views. Thus, underlying the complicity conscience claims of the owners of Hobby Lobby is a subtle sovereignty claim. The religious integralist refuses to obey the civil sovereign's laws regulating the economy or to separate, demanding instead exemptions that undermine public purposes and entail discrete and assignable third-party harms so that they may follow religious law. Deference to this religious integralism on the part of the Court together with its dismissive nod to the problem of third-party harms and the use of the least restrictive means idea to nuke the compelling state interest argument is striking. I argue that ultimately it can only be explained as a nod to that other sovereign whose law is invoked by the religious. Eisenberg is right: the Court failed to defend citizenship entitlements, to acknowledge that the state can and does limit the concept of clergy and to take third-party harms to women seriously. But why? She gives us no clue. I suspect that, deep down, it is for the reasons I gave.

2. Sune Lægaard zeros in on the redundancy question, asking what additional protection 'freedom of religion' provides beyond the general right of associational freedom, what prerogatives it grants in excess of the ordinary autonomy of voluntary associations to choose their purposes, doctrines, leaders, or members and what would justify this. For obvious analytic reasons he focuses on Hosanna-Tabor and the expanded conception of church autonomy it entails. Theorists of church autonomy assume that special protection and unique prerogatives are required for religious freedom and that a theory of religious groups as sui generis entities with corporate rights independent of members' rights and of the polity can do the explanatory and justificatory work. Cleverly deploying the Hohfeldian distinction between liberty rights, claim rights, immunity rights and powers of jurisdictional authority, he correctly observes that it is the latter - the power to change the normative situation of members and employees of religious organizations - that is now at stake. At issue is not simply the claim that the state should not regulate Church matters, but rather that religious organizations have the authority to decide internal matters - and this independent jurisdiction is then taken to justify the claim about non-interference. Implicit in this expanded church autonomy logic is that churches have independent authority to decide what constitutes an internal matter: the state allegedly being both incompetent and without the right (jurisdiction) to judge.

Lægaard deconstructs the contradictions in these arguments for expanded church autonomy with refreshing analytic clarity. He distinguishes between the subject of a right and the source of the right, noting that it is trivially true that individuals 
need protection for communal worship and thus that the subject of the right of religious freedom can be a collective. But even if one construes the collective subject as a sui generis rights holder rather than an aggregate of the rights of its members, this says nothing about the source of the rights it holds or what they are. The claim that church autonomy is grounded in an authority outside the liberal democratic constitution is a claim about the normative sources of law independent of the nature of the holder of the right.

The helpful distinction between subjects and sources of rights shows that independent jurisdictional status of religious organizations does not follow from their claim to be corporate subjects of rights. Indeed, nothing regarding rights follows directly from how one construes the corporate nature of religious organizations. Whether the subjects of rights are individuals or groups, just what rights they have and on what basis are all distinct questions and the answers do not entail one another. As I noted, John Dewey made this point regarding the nature of corporate groups long ago. One enters into the domain of political theology and metaphysics when arguing that because the object of a right to religious freedom is communal, then the subject of the right is a corporate body existing independently of the state with independent normative authority.

I take Lægaard to imply that analysts of the scope of civil law should not adopt an internal religious perspective that cannot admit churches are subject to sovereign secular law, with the competence to determine competences of all groups and to draw the boundaries between the internal and the external. Instead, we must take the perspective of civil law and ensure that accommodations or allocations of internal decisional autonomy are just. The democratic civil polity cannot grant any jurisdictional power claim to the religious that trumps its scope. Civil law can be self-limiting and make exceptions and distinctions for appropriate civil purposes. But the supremacy of civil law is the condition of possibility of any liberal democratic republic.

Lægaard's comparative analysis shows that this assumption undergirds the conception of religious freedom in the European Convention on Human Rights. There, church autonomy is limited by secular human rights and legitimate legislative public purposes. The emerging practice of the European Court of Human Rights does not defer to religious authorities or acknowledge any independent religious jurisdictional standing that states must respect. On the contrary, it is the religious organizations that are bound procedurally and substantively to respect human rights. Lægaard's comment thus returns us to a benign conception of church autonomy, which comports with liberal principles and comes under the jurisdiction of civil law.

It is a pity he did not answer his opening question as to whether freedom of religion as a special right does any important work beyond the protections offered by ordinary associational and expressive freedoms. Does he embrace the reductionist approach? If not, why not? My own preference would be to use the civil freedom of association frame and, when it comes to hard cases, to place the burden of 
proof where it should be, on the religious claimant to show just why their purposes require special treatment and merit exemption from general civil laws required by justice. For this, the relevant dimension of religion would have to be specified, as would the relevant liberal principles. For example, what makes religious non-profits different from other non-profits? Does the difference require distinct forms of accommodation unavailable under the full panoply of liberal rights? Once we drop the 'religion is unique' assumption of the jurisdictional accommodationists, the need for explanation and justification goes all the way down.

3. Jonathan Seglow follows this route indicating how to justify institutional exemptions for religious groups on secular grounds. His analysis pursues a disaggregation strategy regarding institutions run by the religious and types of exemptions that helpfully clarifies the issues. He is right to note that the version of religious pluralism I object to does two things. First, it detaches democratic political authority from its ultimate authors, the people, relocating a portion of that authority to religious corporations deemed self-authenticating sources of binding norms. Second, by placing political authority inside a black box of jurisdictionally autonomous associations, religious legal pluralism endangers the rights and freedoms of individual citizens which democratic constitutionalism is pledged to respect.

Seglow desacralizes the issue of religious institutional accommodation by working with the liberal liberties of conscience, association, expression, privacy, etc. Drawing on Andrew Shorten's analysis, he distinguishes among the purpose, structure and ethos of an organization, between two types of association and two ways they can acquire religious ideals. Thus, there are (1) private associations (schools and businesses) that do not have a religious purpose but are embued with a religious ethos (Hobby Lobby and Hosanna-Tabor) and (2) organizations that provide public services the state would otherwise deliver (charities, hospitals, schools). States foster these through tax exemptions or other ways as a kind of delegation strategy.

I confess I am not convinced this taxonomy can do the work Seglow wants it to do. Curiously schools are placed by Seglow in both categories, so I wonder what he means: if education is a public purpose of the state, would not private schools have to be in the second category unless they were exclusively schools for training priests, rabbis, mullahs or ministers? And would not tax-exempt status render the state complicit with their structure and ethos if they are discriminatory, and involve third-party dignity harms?

Moreover, on Seglow's analysis, structural exemptions pertain primarily to private associations without an official public role, while purpose exemptions protect against cooptation by the state in ways that vitiate ethos and aims of an institution. These pertain to institutions acting as proxies for the state in providing basic services to the public. But I am a bit perplexed by the concept of an 'official' public role ascribed to private associations that carry out public purposes 
such as religious non-profits. In the US, at least, private charities, old age centres, schools, and universities do not have an official public role although they are tax exempt. But religion is not a public purpose of the state. So many questions arise. What justification is there for according religious purpose organizations (churches) tax exemptions? Why would religious schools training priests not get purpose as well as structural exemptions although they do not serve any public purpose in Seglow's sense? More importantly, why should institutions with a religious ethos serving the public - hospitals, clinics, schools - be allowed to discriminate against non-members or refuse to provide health services (contraception) if they receive tax exemptions? How can one reconcile state support for a private institution that violates the public purposes of that state while allegedly carrying out public purposes? How would this differ from a structural exemption?

Seglow also delves into the nature of corporate groups zeroing in on my discussion of corporate legal personhood. Like Lægaard, he is right to point out that, insofar as the subject of rights is concerned, the fact that it can be a group does not contradict the nexus of contracts theory. His co-op example nicely illustrates this point: common interests irreducible to the interests of the contracting individuals can indeed arise once the group is formed, and thus the person of the corporation, on this view, can be a rights holder just as it can under the real entity theory. On the real entity theory, however, the group has prior interests as a group; it preexists and is distinct from individuals who acquire interests merely by combining in some way. But it is unclear what difference this distinction makes. A newcomer to a co-op also finds the group - the cooperative -preexistent. And if in both cases, the subject of rights is a group with collective interests and legal personality, and both are irreducible to the individuals' interests and rights, then absent a metaphysical conception of corporate personality, just how do the two types of groups actually differ and what difference does the distinction make?

Indeed, the purpose of my discussion of the three conceptions of corporate personhood was to show in a Dewey-esque way that they are all indeterminate regarding corporate legal rights and that none can justify the decisions in Hobby Lobby or Hosanna-Tabor. That is why I argued that a political-theological conception of the corporate (and of sovereignty) was doing the work. This is apparently Seglow's point as well. He also seems to conclude that neither purpose nor structure exemptions fit the cases of Hobby Lobby or Hosanna-Tabor and that they could not be justified on secular grounds. It is thus very difficult to justify institutional exemptions that conflict with core public purposes and involve third-party harms. This does not mean that no exemptions are acceptable, but that a secular theory of which ones are remains to be produced.

4. Patrick Loobuyck gets to the heart of what motivates my article: an evolution in the logic of accommodation that is in deep tension with both liberalism and democracy. Expansive, uncompromising demands for exemptions is now the political strategy of those who fail to win at the polls or convince enough people to block anti-discriminatory laws that protect the status equality and civil rights of everyone. We are indeed confronting wolves in sheep's clothing, so it is instruc- 
tive for Europeans to look at the American cases and for Americans to learn from Europe. As I write, a bill is being pushed in Congress called the 'First Amendment Defense Act', aimed at ensuring that organizations and individuals objecting to same sex marriage on religious grounds do not lose their tax exemptions if they refuse to serve, house or do business with same sex couples. Having failed to block the constitutionalization of same sex marriage, demanding exemptions is the default strategy. While very few religious institutions lose tax exemption due to discrimination, the reference to the Bob Jones case is clear.

It is worth noting that some major theorists of church autonomy have shifted from their earlier relatively more tame pre-Smith positions to far more expansive claims post RFRA. Writing in 1984 with the Bob Jones case in mind, Douglas Laycock, a preeminent religious liberty scholar, distinguished between internal and external Church affairs arguing that the former are an enclave where the free exercise clause controls, but when the church or an individual ventures into secular society, it must do so on society's terms. ${ }^{16}$ If a religiously motivated individual or group owns a business, he must serve all; when he participates in government or the secular economy, he must obey the secular rules that apply to all. ${ }^{17}$ By 2008, Laycock (with same sex couples in mind) dropped the internal/external distinction, now arguing that if a religious person enters the secular economy, his right to 'moral integrity' vitiates the obligation to comply with secular rules. He should be accommodated: permitted by law to refuse to do business with same sex couples. ${ }^{18}$ Laycock supported Hobby Lobby, arguing in an amicus brief that large businesses should be entitled to religious exemptions regarding contraception for women because limiting the size of business that can be owned by religious minorities is an historic wrong! Perhaps we need Brian Barry here after all.

Less rigid than Barry, for Loobuyck the question is what the standard liberal freedoms require or permit regarding group autonomy and religious freedom. Like Seglow, he reinstates the internal/external and public/private distinctions regarding institutional structure, ethos and accommodation. Private religious voluntary associations may restrict the equality of members but not that of outsiders. But private associations (membership groups) are distinct from entities functioning as employers that organize public services like health care or education in non-profits. The default position is that those do not enjoy more privileges than other

16 Douglas Laycock, 'Tax Exemptions for Racially Discriminatory Schools', Texas Law Review 60 (1982): 259-77 at 263. For an earlier article defending NLRB v. Catholic Bishop, 440 US 490 (1979), ruling that the National Labor Relations Board lacks jurisdiction over religious schools' employment policies; see Douglas Laycock, 'Towards a General Theory of the Religion Clauses: The Case of Church Labor Relations and the Right to Church Autonomy', Columbia Law Review 81 (1981): 1373-417.

17 To be sure, he drew this distinction in order to place the evangelical Bob Jones University in the former rather than in the latter category (supporting tax exemptions even though it discriminated on the basis of race).

18 James Oleske Jr., 'The Evolution of Accommodation: Comparing the Unequal Treatment of Religious Objections to Interracial and Same-Sex Marriage', Harvard Civil Rights-Civil Liberties Law Review 50(1) (2015): 99-152. 
associations. Laws regulating non- and for-profit employers that serve the public must be the same for all, especially because, as Loobuyck notes, employment is a very scarce commodity and many accept jobs at institutions owned or run by the religious because they have little choice. US anti-discrimination law has the concept of bona fide occupational qualification (BFOQ). So if a particular characteristic (religion) is necessary for the job qualification, then there is no odious discrimination and exemptions are justifiable on liberal grounds. But American law also has the concept of public accommodation, stipulating that for-profit institutions serving the general public must serve the general public - everyone.

That said I still remain dubious that the distinctions between public and private, internal/external, membership association/organization serving the public suffice because line drawing in law is both unavoidable and imperfect. Clearly, the liberal democratic civil polity must do the line drawing and 'accommodate' in ways that comport with liberal democratic principles. But regulation of self-regulation also of private membership associations is unavoidable and desirable. This is so because third-party harms can occur when odious discrimination is tolerated in large 'private' institutions. More work has to be done to justify why churches or other 'private' associations set up by the religious may enjoy tax exemptions if they violate fundamental non-discrimination principles. The complicity argument can be run both ways. Why should tax dollars be used to support institutions that are allowed to discriminate against women, endorsing and reinforcing status harms throughout the society?

I agree that conditioning the receipt of government funds on internal practices that match public values is possible and desirable within a liberal framework - but I would apply this criterion to private as well as public service organizations! Since freedom of association is a core liberal principle, the liberal state may not require congruence between the structure of religious organizations or entities run by them with democratic institutions. But subsidizing institutions practicing odious discrimination is illiberal.

5. A propos, Roland Pierik distinguishes between two types of liberalism - toleration-leaning and egalitarian-leaning - arguing that the accommodationism I describe conflicts with the latter but is an exemplar of the former, so I'm wrong to call it illiberal. I should realize that we face a divide within liberalism. Attending to the fault line within liberalism would aid in the fight against anachronisms. He concurs that the accommodationism I criticize relies on a conception of religious freedom that questions state sovereignty and accords immunities and powers to religious groups justified by a 'pre-modern' idea of legal plurality and the twoworlds theory. But he insists that this stance is part and parcel of an older liberal tradition that has to be understood and argued against. Indeed Pierik claims that what is 'underdeveloped' in my article is the political struggle over which of the two incompatible liberal interpretations of religious freedom should guide exemption policies today, rather than an 'academic dispute about the correct interpretation of the liberal-democratic tradition'. 
I do not think this quite fair and I could level a similar charge against him. That my concern is with the politics of accommodation and the political struggles, strategies and stakes involved should be obvious. My purpose is to reveal just what these political stakes are. It is Pierik who seems invested in an academic dispute over the concept and tradition of liberalism, apparently irritated that I call the accommodationism I criticize illiberal, i.e., incompatible with liberal democracy. Yet he grants my arguments and confirms that the version of accommodationism he calls toleration-leaning is incompatible with liberal democracy! Moreover, he has taken on board my most important arguments regarding civil democratic sovereignty and the polity's supreme competence to decide competences of other entities, acknowledging that this and religious status group legal pluralism are the deep stakes of the new accommodationism.

I find Pierik's comment both interesting and unconvincing. His distinction between toleration and equality orientations is interesting as I myself, in another piece, juxtaposed what Alfred Stepan called the 'twin tolerations' to egalitarianism, arguing that for the US it is the latter, not the former that is at the heart of the first amendment religion clauses. ${ }^{19}$ They are not premised on what Rainer Forst has called the permission conception of toleration, in which state power permits the existence and practice of other religions but treats them unequally, privileging a dominant established religion. Pierik calls this first version of toleration 'liberal' - i.e., the one institutionalized in Europe with the principle of cuius rejio eius religio coupled with permission to believers of other faiths to emigrate or to practice under strictly regulated conditions.

This solution set the stage for liberal tolerance. But it is misleading to call it liberal not only because it is not egalitarian (or Rawlsian) but also because it lacked the core liberal principle of individual personal ethical freedom - what we now call ethical autonomy -and what Locke called individual freedom of conscience. The Lockean version was liberal. Note that it did not permit accommodation: Locke differentiated between the spheres of religious belief and secular affairs and insisted that the civil law applies to all. Nor was his liberal tolerance egalitarian: Catholics and atheists could not be tolerated thought Locke, but that was for (misguided) civil political reasons pertaining to issues of civic loyalty and trustworthiness.

I also contest the tight connection Pierik draws between Christianity and toleration-leaning 'liberalism'. Obviously liberalisms emerged in Europe and the Reformation, state making and democratic revolutions played key roles in the trajectory en route to liberal democracy. But genesis is not structure and one historical path does not mean there are no other paths to a similar end. The Ottoman Millet system was also pluralist, tolerant, and 'liberal' in Pierik's sense. There was as tight a link between Islam and toleration-leaning 'liberalism' regarding people of the book, as there was in post-reformation Christian Europe. It would not be at 
all odd for a Muslim organization in the US to make similar accommodation claims to the Protestants in Hobby Lobby and they do. ${ }^{20}$ My point is that we must distinguish between liberal and illiberal pluralism. I had hoped my discussion of rights, civil society, and ethical independence for individuals juxtaposed to privileges, immunities and powers for autonomous (unregulated) religious status groups were enough to bring that point home.

Nor am I convinced that the illiberal status group religious pluralism we are confronting that deploys the rhetoric of multiculturalism, tolerance, fairness and even equality (they take our language) is really anachronistic. Medieval and early twentieth century versions of jurisdictional pluralism are invoked as arguments against 'monistic' state sovereignty, mobilized to reinvent the old illiberal tolerance in contemporary guises. We face a new 'post-secularism' that uses the rhetoric of liberalism, democracy, equality, and justice for purposes that would undermine these very achievements of liberal democratic constitutionalism. One has to ask why 'anachronistic' tolerance-leaning orientations are being resurrected when they have been surpassed by liberal democratic and egalitarian principles. At issue, in the US at least, is not protection of the religious from secularist autocrats. Rather, it is an autocratic illiberal version of 'religious freedom' and powerbids by religious at the expense of liberal democratic and secular elites, that are on the rise in the twenty-first century everywhere. We should remain very alert to the dangers to our liberties and liberal democracy generally. 